\title{
PRECAST CONCRETE SYSTEMS IN DEVELOPING VS. INDUSTRIALIZED COUNTRIES
}

\author{
Gul Polat \\ Department of Civil Engineering, Istanbul Technical University, Istanbul, Turkey \\ E-mail:polatgu@itu.edu.tr \\ Received 23 Mar. 2009, accepted 26 Nov. 2009
}

\begin{abstract}
Precast concrete technology is recognized worldwide as offering significant advantages. Despite the advantages they offer, precast concrete building systems' share in both Turkey and the U.S. is very low, especially when compared to many European countries. Since Turkey is a developing country that is technologically dependent on the developed world, low share of industrialized building systems is highly expected in that country. However, the U.S. is a developed and industrialized country, so it was very interesting to see that these systems are not extensively used in that country either. This study investigated the factors that prevent the extensive use of precast concrete systems in the U.S. and Turkey through an extensive questionnaire survey. The survey results revealed that the perceptions of the American vs. Turkish respondents on most of the factors that affect the use of precast concrete systems are significantly different from each other. While American respondents considered size and load restrictions on transportation, poor communication among parties, and lack of qualified contractors specialized in precast concrete systems as three most important barriers to the extensive use of precast concrete systems in the U.S. building construction market, Turkish respondents ranked lack of good communication among parties and lack of structural engineers and contractors specialized in precast concrete systems as the most important three factors that prevent the extensive use of these systems in Turkey. This study indicated that precast concrete users and manufacturers should recognize that the main reasons for low utilization of precast concrete systems predominantly depend on the prevailing conditions of the country in question.
\end{abstract}

Keywords: precast concrete, building systems, developing countries, industrialized countries, questionnaire, Turkey, USA.

\section{Introduction}

The construction industry and its activities have an important role in socio-economic development, environment, and quality of life. In contrast to its significant impact on national economies and people's lives, the construction industry is typically characterized by labour intensive technology, hard labour conditions, low productivity, and high risks (Kazaz et al. 2008). These problematic business conditions mainly result from the slow integration of technological advances and industrialization principles such as computer-aided construction, automation, standardization, modularization, etc. to the construction industry (UNEP Report 2002). Industrialisation of construction refers to the rationalisation of the construction process by promoting off-site manufacturing (Alinaitwe et al. 2006). Precast concrete is one of the construction methods that use the principles of industrialization in the construction process.

The use of precast concrete technology rather than cast-in-situ production promises several advantages to all project participants. Precast concrete components are produced with computer-aided technology using hightech machinery under laboratory conditions in precast manufacturers' plants, which brings about high quality and high durability products (Neville 2005; Hamill et al.
2006). Also, enhanced standardization and modularization of components can be achieved (Kale and Arditi 2006), and better architectural appearance may be attained (Manrique et al. 2007; Soentanto et al. 2007). Moreover, the project duration shortens as the production and erection processes are not affected by the vagaries of weather and great fluctuations in labourers' productivity; and the project cost goes down since the project duration gets shorter, fewer on-site labourers are employed, and fewer materials are wasted during the production and erection processes (e.g., Chan and $\mathrm{Hu}$ 2002; Eastman et al. 2003; Sacks et al. 2004; Hamill et al. 2006; Manrique et al. 2007; Tam et al. 2007). The use of precast concrete systems may also help in improving health and safety issues throughout the construction process because fewer activities are carried out on site, which ultimately reduces the number of accidents that may happen (Lam et al. 2007). In addition, precast concrete contributes to sustainable practices by incorporating integrated design, using materials efficiently, and reducing construction waste, site disturbance, and noise (VanGeem 2006).

Precast concrete systems became one of the major construction methods in many European countries, especially after World War II (Arditi et al. 2000), and they are still used extensively in many eastern and northern European countries. Indeed, the average share of precast con- 
crete systems in the construction industry across the European Union is $20-25 \%$, and it goes up to $40-50 \%$ in the northern European countries (YEMAR Report 2006). In contrast to the European countries, the use of these systems in Turkey and the U.S. is very low. The share of reinforced concrete construction supplied by precast producers is $6 \%$ in the U.S. (Sacks et al. 2004), and it is only 2\% in Turkey (YEMAR Report 2006). Precast concrete systems' share of the overall building construction market in the U.S. is approximately $1.2 \%$ (Eastman et al. 2003; Sacks et al. 2004).

Turkey is accepted as a lower-middle income developing country in the World Bank classifications. Like many other developing countries, it is technologically dependent on the developed world. Thus, it was not surprising to see that the share of industrialized building systems is very low in Turkey. On the other hand, it was very interesting to see that these systems are not extensively used in the U.S. either.

The main reasons for the low utilization of precast concrete systems in the Turkish construction industry were recently discussed by Tokman and Eryilmaz (2004), Agrali (2005, 2006), YEMAR Report (2006), and Polat (2008a). According to these sources, there are four main reasons why precast concrete systems are not extensively used in Turkey, which include lack of qualified workforce specialized in precast concrete structures, limited variety of precast concrete components, inferior performance of precast concrete systems in the recent earthquakes occurred in Turkey, and public policy and political concerns. All of these factors seem to be reasonable given the special circumstances that dominate not only the Turkish construction industry but also the Turkish precast concrete industry.

Two recent studies (Arditi et al. 2000; Polat 2008b) comprehensively addressed the factors that affect the use of precast concrete systems in the U.S. building construction industry. Arditi et al.'s (2000) study was based on a survey that had been carried out in 1995 and revealed that lack of expertise in precast concrete design and contractors' unawareness of significant cost savings were two of the main factors that prevented the extensive use of these systems in the U.S. building construction industry. Polat's (2008b) study indicated that most of the prerequisite conditions favourable for the extensive use of precast concrete systems, which existed in 1995, either prevailed in 2006 or have changed for the better in the last 11 years. Polat (2008b) also found that there is a major shortage of expert personnel that can design and manage precast concrete building systems. In addition to the lack of expertise, size/weight restrictions on truck loads have a significant impact on the design of precast concrete systems, which in turn hinder the extensive utilization of these systems.

The main objective of this research was to identify whether the factors that prevent the extensive use of precast concrete systems in Turkey are significantly different from those in the U.S. For this purpose, an extensive survey was conducted.

\section{Research methodology}

The main reasons why precast concrete systems are not extensively used in the U.S. and in the Turkish building construction markets were investigated through a mail survey, which was developed using the information collected after a survey of the literature. The questionnaires were sent to 100 contractors, 100 designers, and 100 precast concrete manufacturers in the U.S., and 100 contractors, 100 designers, and 95 precast concrete manufacturers in Turkey.

Engineering News Record's (ENR's) list of the "Top 400 contractors" (2006) was used to select 100 contractors in the U.S. Each contractor's workload in general building contracts was calculated by multiplying the value of total contracts by the percent of general building contracts, and then the values of general building contracts were sorted in a descending order. These 100 contractors ranked between $2^{\text {nd }}$ and $387^{\text {th }}$ positions in the ENR's list of "Top 400 contractors".

Engineering News Record's (ENR's) list of the "Top 500 designers" (2006) was used to select 100 American design firms to which the questionnaires were mailed. Since the questionnaire included both engineering and architecture related questions, only the firms classified as architect-engineer (AE), engineer-architect (EA), architect-engineer-planner (AEP), and engineer-architectplanner (EAP) were considered for selection. The final selection was made after multiplying the firms' calculated billings with their percentage of general building activity; hence, the firms were sorted in descending order of their general building billings. The first 100 designers ranked between the $2^{\text {nd }}$ and $498^{\text {th }}$ positions in ENR's list of the "Top 500 design firms".

The Precast/Prestressed Concrete Institute (PCI) was established in 1954 to promote greater understanding of the design and use of precast and prestressed concrete and to represent the industry. Today, there are about 150 PCI Producer member companies with 247 certified plants in the U.S. The questionnaire for precast concrete manufacturers was mailed to 100 of the 247 PCI certified plants. To select the PCI certified precast concrete manufacturers to which questionnaires would be mailed, the manufacturers had to be identified and classified according to their product types. Since the questionnaire used in the survey includes both engineering and architecture related questions, manufacturers that produce architectural precast units, beams, columns, joists, and hollowslabs were selected for the survey. The addresses of the 100 PCI certified precast concrete manufacturers were obtained from the PCI's Membership directory (2006).

The membership directories of the Turkish Contractors Association (TCA) and the Association of Turkish Consulting Engineers and Architects (ATCEA) were searched for 100 contractors and 100 design firms involved in building projects. The Turkish Precast Concrete Association (TPA) was established in 1984 to promote the use and dissemination of precast concrete in the country and to represent the industry. TPA has currently 25 members. However, according to unofficial figures, there are about 95 precast concrete firms that produce 
precast concrete products in Turkey. The addresses of these 95 manufacturers were obtained from TPA.

In order to see if the perceptions of the American vs. Turkish respondents on the factors that prevent the extensive use of precast concrete systems are significantly different from each other, the Mann-Whitney test was conducted by using the statistical package SPSS $\AA$. This non-parametric test was appropriate in this case because the ordinal data were collected via a 4 point scale (i.e., $0=$ not important, $1=$ fairly important, 2 = important, $3=$ very important) to rate the perceptions of the respondents (Field 2005).

The Mann-Whitney test is a powerful nonparametric test for comparing two independent populations. It performs a hypothesis test of the equality of two population medians and calculates the corresponding point estimate and confidence interval (Conover 1998; Norusis 2000; Field 2005). If $p<0.05$, the null hypothesis that there is no significant difference between the medians of the samples is rejected and the alternative hypothesis that there is a significant difference between the medians of the two populations is accepted at $95 \%$ confidence level (Field 2005).

\subsection{Discussion of findings}

While only 47 of the 300 questionnaires that were mailed to 100 contractors, 100 designers and 100 manufacturers in the U.S. were answered by the addresses, 134 of the 295 questionnaires that were sent to the Turkish counterparts were returned duly completed. The response rates by type of respondent are presented in Table 1.

Table 1. Response Rates of Surveys

\begin{tabular}{|c|c|c|c|c|c|}
\hline & \multirow{2}{*}{$\begin{array}{l}\text { Type of } \\
\text { recipient }\end{array}$} & \multicolumn{3}{|c|}{ Number of questionnaires } & \multirow{2}{*}{$\begin{array}{c}\text { Rate of } \\
\text { response } \\
(\%)\end{array}$} \\
\hline & & Mailed & $\begin{array}{c}\text { Wrong } \\
\text { address }\end{array}$ & Answered & \\
\hline \multirow{3}{*}{ 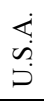 } & Contractors & 100 & 0 & 14 & 14 \\
\hline & Design firms & 100 & 0 & 14 & 14 \\
\hline & Manufacturers & 100 & 3 & 19 & 19 \\
\hline \multirow{4}{*}{ 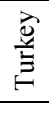 } & Contractors & 100 & 0 & 57 & 57 \\
\hline & Design firms & 100 & 0 & 41 & 41 \\
\hline & Manufacturers & 95 & 0 & 36 & 38 \\
\hline & Total & 595 & 3 & 181 & 31 \\
\hline
\end{tabular}

Of the Turkish respondents, 17 of the 57 contractors (30\%) and 9 of the 41 designers (22\%) indicated that they had never used precast concrete systems in their building projects, whereas only 1 of the 14 respondent designers in the U.S. (7\%) stated that they had not used these systems. The answers to this question indicate that while the majority of the designers and all of the contractors use precast concrete systems in their building projects in the U.S., $27 \%$ of the Turkish respondents do not use these systems in their building projects. This finding seems reasonable given the fact that the use of these systems in Turkey is lower than it is in the U.S. The highest rate of response was achieved in the survey of precast concrete manufacturers in the U.S. as was the case in Arditi et al.'s (2000) survey. The main reason behind this high response rate may likely be that precast concrete manufacturers see the survey as an opportunity to promote their products, express their ideas about the systems they produce, and declare their objections against established negative myths about precast concrete systems. In contrast with the American manufacturers, the lowest response rate was achieved in the survey of manufacturers in Turkey (see Table 1). It seems that Turkish manufacturers were not interested in promoting their products.

\subsection{Factors preventing the use of precast concrete systems in the U.S. and Turkey}

Although the use of precast concrete systems promises several significant advantages, the use of these systems in the U.S. and in Turkey is still very low. According to Sacks et al. (2004), labour costs, climate, and the relative costs of alternative construction methods influence the market share of precast concrete systems. This section discusses the factors that may prevent the extensive use of precast concrete systems, and compares the impact of those factors on the use of precast concrete systems in the U.S. and the Turkish building construction markets.

\section{- Cost of precast concrete components}

The ultimate goal of all project participants is to lower overall project cost and thereby increase the profit margins. Therefore, the cost of using precast concrete components in a project rather than employing traditional construction methods plays a significant role in the extent to which precast concrete systems are preferred (Sacks et al. 2004). The contractors, designers, and manufacturers were asked how they would rate the cost of precast concrete components as a factor that prevents the extensive use of precast concrete systems. On a scale of 0-3 (where $0=$ Not Important, 1 = Fairly Important, 2 = Important, and 3 = Very Important), American respondents scored on average1.28 and Turkish respondents scored 1.44, both of which are higher than "fairly important" (see Tables 2 and 3). The Mann-Whitney test indicates no significant difference between the answers of the American and Turkish respondents at 95\% confidence level.

There may be three main reasons behind this slight difference. One is that there are only few qualified precast concrete manufacturers in the Turkish precast concrete industry (Tokman and Eryilmaz 2004; YEMAR Report 2006). The lack of serious competition may create higher prices. Second, Turkish contractors may not be totally aware of the capabilities and advantages of using precast concrete components such as shorter project duration, less material waste, fewer labourers working on site, and enhanced health and safety, which in turn may compensate for the relatively higher cost of precast concrete systems, because of the inadequacy of precast concrete manufacturers' advertising and/or promotional activities about their products (Tokman and Eryilmaz 2004; YEMAR Report 2006). Third, in most developing countries, the cost of exploiting labour-intensive methods is much lower than the cost of implementing advanced technologies that require more skilled labour due to several reasons such as low wages of labourers, insufficient 
funds for R\&D, slow diffusion of innovation and technological developments, etc. (Kaming et al. 1994; Oral et al. 2003). Low wages of labourers is commonly true in developing countries. Indeed, wages are much lower in developing countries than those in industrialized countries (OECD Report 2004). However, it should be kept in mind that although wages in developing countries are low, labourers are generally untrained, underqualified, unskilled, and inexperienced (DPT Report 2004; Alinaitwe et al. 2007; Kazaz et al. 2008; Alinaitwe et al. 2009).

Table 2. Factors Preventing the Extensive Use of Precast Concrete Systems in the U.S.

\begin{tabular}{|c|c|c|c|c|}
\hline \multirow{2}{*}{$\begin{array}{c}\text { Factors Preventing the } \\
\text { Extensive Use of Precast } \\
\text { Concrete Systems in the U.S. }\end{array}$} & \multicolumn{3}{|c|}{$\begin{array}{l}\text { Importance Scores of } \\
\text { the Respondents }\end{array}$} & \multirow{2}{*}{$\begin{array}{l}\text { Aver- } \\
\text { age } \\
\text { Scores }\end{array}$} \\
\hline & Con. & Des. & Man. & \\
\hline $\begin{array}{l}\text { Cost of precast concrete } \\
\text { components }\end{array}$ & 1.50 & 1.54 & 0.95 & 1.28 \\
\hline $\begin{array}{l}\text { Size and load restrictions on } \\
\text { transportation }\end{array}$ & 1.93 & 2.08 & 1.53 & 1.81 \\
\hline $\begin{array}{l}\text { Variety of precast concrete } \\
\text { components }\end{array}$ & 1.50 & 2.00 & 0.53 & 1.24 \\
\hline $\begin{array}{l}\text { Performance of precast con- } \\
\text { crete systems in earthquakes }\end{array}$ & 1.00 & 0.92 & 0.16 & 0.63 \\
\hline $\begin{array}{l}\text { Availability of qualified } \\
\text { structural engineers special- } \\
\text { ized in precast concrete } \\
\text { systems }\end{array}$ & 1.36 & 0.46 & 1.95 & 1.35 \\
\hline $\begin{array}{l}\text { Availability of contractors } \\
\text { specialized in precast con- } \\
\text { crete systems }\end{array}$ & 1.57 & 0.69 & 1.79 & 1.41 \\
\hline $\begin{array}{l}\text { Owners' capability of pro- } \\
\text { viding good communication } \\
\text { among parties }\end{array}$ & 1.57 & 0.77 & 2.05 & 1.54 \\
\hline $\begin{array}{l}\text { Availability of labourers } \\
\text { specialized in precast con- } \\
\text { crete systems }\end{array}$ & 1.07 & 0.46 & 1.16 & 0.93 \\
\hline $\begin{array}{l}\text { Conformity between differ- } \\
\text { ent precast concrete systems }\end{array}$ & 1.43 & 0.92 & 0.95 & 1.09 \\
\hline Labour unions' attitude & 0.71 & 0.92 & 1.11 & 0.93 \\
\hline $\begin{array}{l}\text { Occupants' level of satisfac- } \\
\text { tion with precast concrete } \\
\text { structures }\end{array}$ & 1.00 & 0.54 & 0.26 & 0.56 \\
\hline
\end{tabular}

\section{- Size and load restrictions on transportation}

Delivery of pre-cast concrete components from manufacturers' plants to a construction site often brings about difficulties for contractors. This problem is especially experienced in construction sites that are located in the heart of cities, where traffic congestion is a severe problem and there are strict size and load restrictions on transportation (Alinaitwe et al. 2006; Polat 2008a, b). The allowable weights and sizes of loads are limited by the carrying capacity of bridges and pavements and by the horizontal and vertical clearances in tunnels and underpasses (Arditi et al. 2000; Polat 2008b). In addition to the weight/size limitations specified by highway agencies,

\footnotetext{
${ }^{1}$ Scale $0-3 ; 0=$ Not Important, 1=Fairly Important, 2=Important, $3=$ Very Important
}

Table 3. Factors Preventing the Extensive Use of Precast Concrete Systems in Turkey

\begin{tabular}{|c|c|c|c|c|}
\hline \multirow{2}{*}{$\begin{array}{c}\text { Factors Preventing the } \\
\text { Extensive Use of Precast } \\
\text { Concrete Systems in Turkey }\end{array}$} & \multicolumn{3}{|c|}{$\begin{array}{l}\text { Importance Scores of } \\
\text { the Respondents }\end{array}$} & \multirow{2}{*}{$\begin{array}{l}\text { Aver- } \\
\text { age } \\
\text { Scores }\end{array}$} \\
\hline & Con. & Des. & Man. & \\
\hline $\begin{array}{l}\text { Cost of precast concrete } \\
\text { components }\end{array}$ & 1.56 & 1.56 & 1.11 & 1.44 \\
\hline $\begin{array}{l}\text { Size and load restrictions on } \\
\text { transportation }\end{array}$ & 1.84 & 1.83 & 1.50 & 1.74 \\
\hline $\begin{array}{l}\text { Variety of precast concrete } \\
\text { components }\end{array}$ & 1.40 & 1.63 & 1.22 & 1.42 \\
\hline $\begin{array}{l}\text { Performance of precast con- } \\
\text { crete systems in earthquakes }\end{array}$ & 1.53 & 1.51 & 1.36 & 1.48 \\
\hline $\begin{array}{l}\text { Availability of qualified } \\
\text { structural engineers special- } \\
\text { ized in precast concrete } \\
\text { systems }\end{array}$ & 1.79 & 1.78 & 1.92 & 1.82 \\
\hline $\begin{array}{l}\text { Availability of contractors } \\
\text { specialized in precast con- } \\
\text { crete systems }\end{array}$ & 1.84 & 1.80 & 1.97 & 1.86 \\
\hline $\begin{array}{l}\text { Owners' capability of pro- } \\
\text { viding good communication } \\
\text { among parties }\end{array}$ & 1.93 & 1.76 & 1.97 & 1.89 \\
\hline $\begin{array}{l}\text { Availability of labourers } \\
\text { specialized in precast con- } \\
\text { crete systems }\end{array}$ & 1.67 & 1.56 & 1.44 & 1.57 \\
\hline $\begin{array}{l}\text { Conformity between differ- } \\
\text { ent precast concrete systems }\end{array}$ & 1.68 & 1.67 & 1.44 & 1.61 \\
\hline Labour unions' attitude & - & - & - & - \\
\hline $\begin{array}{l}\text { Occupants' level of satisfac- } \\
\text { tion with precast concrete } \\
\text { structures }\end{array}$ & 1.16 & 1.00 & 0.83 & 1.02 \\
\hline
\end{tabular}

there are several restrictions on the travel times of overdimension vehicles. These restrictions may bring about severe delays in the delivery of precast concrete components to the construction site, which may eventually impede the erection process. Precast concrete components are bulky and heavy materials (Jang and Skibniewski 2008) so weight and size restrictions on loads and the traffic congestion apply in most cases (Polat 2008a, b). Indeed, these components have to be carried to the construction site in small batches with frequent deliveries. For instance, most of the pre-cast concrete pieces used for the construction of the 286,000 sq ft Aurora Municipal Center (AMC) and the 241,000 sq $\mathrm{ft}$ parking structure were so large and heavy (some weighing upwards of 28 tons) that the trucks only carried an average of 1.4 pieces per trip (Todd et al. 2004). A question related to the size and load restrictions on transportation were asked to the contractors, designers, and manufacturers. While the American respondents ranked this issue first among other factors with an average score of 1.81, their Turkish counterparts scored on average 1.74 (see Tables 2 and 3). The average scores are very close, and both the American and Turkish respondents scored higher than "fairly important," and close to "important." The Mann-Whitney test suggests that there is no significant difference between the answers of the American and Turkish respondents.

\footnotetext{
2 Scale $0-3 ; 0=$ Not Important, 1=Fairly Important, 2=Important, $3=$ Very Important
} 


\section{- Variety of precast concrete components}

Although there is no consensus on how the use of precast concrete components in building projects actually influences the architectural performance of precast concrete buildings, it is sometimes claimed that architectural creativity is negatively influenced by limited variety of precast concrete components. Some architects believe that their architectural creativity suffers when they use precast concrete components. They claim that since producing a large variety of precast concrete components may cost much more than producing them in situ, precast concrete building systems have tendency towards excessive repetitiveness (Alinaitwe et al. 2006). On the other hand, some other architects insist that most of the complex patterns that cannot be produced by employing traditional construction methods can easily be achieved by using precast concrete components. They believe that precast concrete systems allow more flexible designs (Arditi et al. 2000; Polat 2008a, b). Contractors, designers, and manufacturers were asked to rate the importance of architectural creativity on the low use of precast concrete systems. The American respondents scored on average 1.24 and the Turkish respondents 1.42 , which are higher than "fairly important" (see Tables 2 and 3). The Mann-Whitney test indicates that there is no significant difference between the American and Turkish respondents' perceptions on this issue.

\section{- Performance of precast concrete systems in earthquakes}

Uncertain and volatile structural performance of precast concrete systems under high seismic loads is one of the most important disadvantages of these systems (Polat 2008a, b). Indeed, precast concrete structures showed uncertain performances in earthquakes so far. The structural performance of precast concrete structures was noticeably well in the 1995 Kobe earthquake (Muguruma et al. 1995), whereas their performance was very poor in the 1992, 1995 and 1999 earthquakes that occurred in Turkey (Sezen and Whittaker 2006). Precast concrete buildings showed great deformations and underwent severe failures due to distress in the connections in those earthquakes in Turkey. On the other hand, it is surprising to see that the structural frames of precast concrete building systems did not show any sign of distress in the connections or elsewhere during the 1985 Mexico earthquake (Camba and Meli 1993). In the 1994 Northridge earthquake, most of the precast structures close to the epicentre showed very small deformations, whereas some of them that were not so close underwent severe failures (Iverson and Hawkins 1994). Undoubtedly, the inconsistent structural performance of precast concrete systems may prevent the extensive use of that kind of systems. A question related to this issue was asked to contractors, designers, and manufacturers. The average importance score given by the Turkish respondents 1.48 (which is higher than "fairly important") was approximately 2.5 times higher than the average score given by their American counterparts 0.63 (which is below "fairly important") (see Tables 2 and 3).
The Mann-Whitney test suggests that inconsistent performance of precast concrete systems in earthquakes concerns the Turkish respondents much more than it does their American counterparts.

Although the use of precast concrete components in seismic regions of the U.S. had been limited due to the uncertainty about their performance during earthquakes (Priestley and Tao 1993), that kind of consideration has drastically changed recently due to several research and development programs conducted mostly through the support of PCI and the National Science Foundation (NSF) in order to develop a more comprehensive seismic design methodology for precast concrete structures (Polat $2008 \mathrm{~b}$ ). On the other hand, the widespread damage to the precast concrete industrial facilities caused by the 1992 , 1995 and 1999 earthquakes in Turkey had a significant impact on the economy of the country. Since nearly $93 \%$ of Turkey is located in the heart of an active seismic zone and major earthquakes frequently strike, it is very normal that the performance of precast concrete structures under seismic loads is one of the most important concerns of Turkish contractors, designers, and manufacturers (Tokman and Eryilmaz 2004; Sezen and Whittaker 2006; YEMAR Report 2006).

\section{- Availability of qualified structural engineers specialized in precast concrete systems}

Rigorous structural analysis, design, and construction of connections may likely improve the structural performance of precast concrete building systems, especially under seismic loads (Arditi et al. 2000; Arslan et al. 2003; Sezen and Whittaker 2006). Since the lack of qualified civil engineers and architects specialized in precast concrete systems results in poor design, poor plant management and production, and poor erection practices, the civil engineering and architecture curricula in universities should provide a thorough coverage of these systems (Polat 2008a, b). However, the current engineering and architectural curricula do not provide adequate education about precast concrete systems from the structural, architectural and managerial standpoints in Turkey (Agrali 2005; Polat and Damci 2007; Polat 2008c) as well as in many other countries such as the U.S. (Arditi et al. 2000; Polat 2008b). Contractors, designers, and manufacturers were asked to rate the importance of the lack of qualified engineers in precast concrete systems on the low share of these systems. The average importance scores given by the American and Turkish respondents were 1.35 (which is higher than "fairly important") and 1.82 (which is higher than "fairly important" and close to "important"), respectively (see Tables 2 and 3 ).

It appears that the Turkish respondents consider the lack of qualified structural engineers as one of the major barriers to the extensive use of industrialized building systems more than their American counterparts do. Indeed, the Mann-Whitney test suggests that the lack of qualified structural engineers in precast concrete systems prevents the extensive use of these systems in Turkey significantly more than it does in the U.S. It can be inferred from the survey results that the current state of the 
architecture/engineering curricula to teach the know-how of precast concrete systems in the Turkish universities is deficient and more so than in American universities. Indeed, according to the official figures provided by the Higher Education Institute (YOK), there are 88 universities in Turkey, and 47 of them have civil engineering department and 40 of them have architecture department. 14 of the $47(30 \%)$ civil engineering departments and 3 of the $40(8 \%)$ architecture departments have undergraduate courses regarding precast concrete systems in their academic curricula. Moreover, the academic curricula of the 12 of the $47(26 \%)$ civil engineering departments and 4 of the $40(10 \%)$ architecture departments cover the graduate courses regarding precast concrete systems. It should be noted that all of these courses are elective and they provide students with theoretical knowledge rather than practical experience (Polat and Damci 2007).

\section{- Availability of contractors specialized in precast concrete systems}

The supply chain of precast concrete systems involves complex information and material flows between the project participants including the manufacturer, contractor, and designer. Managing the entire supply chain of precast concrete systems requires a good level of coordination among these parties. Obviously, the project participants can benefit from the use of precast concrete systems as long as timely deliveries of precast concrete components are achieved, and the constraints on transportation, manufacturers' daily production capacity, storage yard availability, etc., are overcome by means of rigorous planning and efficient management of the project. Contractors are one of the key participants in precast concrete supply chains. Since contractors are responsible for the organization and erection of precast concrete building systems, they need to achieve timely deliveries of precast concrete components in the right sequence for the erection schedule and coordinate more complex relationships. Contractors' expertise in managing industrialized building projects would help in disseminating the extensive use of precast concrete systems (Polat 2008a). The contractors, designers, and manufacturers were asked how they would rate the importance of lack of contractors specialized in precast concrete systems on the low share of these systems. While the American respondents scored on average 1.41, the Turkish counterparts scored 1.86 (see Tables 2 and 3). The scores refer to higher than "fairly important," and close to "important," respectively. The Mann-Whitney test indicates that the American and Turkish respondents' perceptions of this issue are significantly different at $95 \%$ confidence level. This difference may result from that the majority of contractors are small and medium-sized enterprises (SMEs) in Turkey (Acar et al. 2005). SMEs generally face severe problems such as insufficient know-how, low level of technology usage, weakness in innovation and technological developments, lack of trained staff, poor university-industry interactions, and inadequate financial resources (OECD Report 2004), which may in turn bring about suffering specialization in the Turkish construction industry.

\section{- Owners' capability of providing good communication among parties}

Speedy erection of the building system and low project cost are two of the significant advantages that precast concrete systems offer. Undoubtedly, these benefits can be achieved as long as a good level of communication among the parties involved in a construction project is achieved both in the design and construction stages. Otherwise, severe delays in production and erection schedules, substantial cost overruns, and constructability problems may likely be experienced. While any inefficiency in the information flow between the designer and manufacturer in the design stage may bring about huge amount of reworks, the contractor's poor communication with the designer and the manufacturer in the construction stage does not only cause constructability problems but also impedes the erection process (Polat 2008a). The contractors, designers, and manufacturers were asked how they would rate the importance of the need for better communication among parties when precast concrete components are used in a building project. The average importance scores given by the American and Turkish respondents were 1.54 (which is higher than "fairly important") and 1.89 (which is higher than "fairly important" and close to "important"), respectively (see Tables 2 and 3 ), a difference that was not statistically significant.

\section{- Availability of labourers specialized in precast concrete systems}

While lack of qualified civil engineers and architects specialized in precast concrete systems results in inadequate analysis, poor design and substandard production practices, lack of qualified labourers in precast concrete systems bring about poor erection practices, which ultimately lead to severe problems such as inferior structural performance due to distress in the connections (Polat 2008a). Precast concrete components are prefabricated in manufacturers' plants, but they are assembled and erected on site by construction labourers. The expertise level of the labourers responsible for the erection of precast concrete structures is vital for the performance of these structures under high seismic loads as improperly formed connections bring about poor structural performance in precast concrete frame structures under extreme vertical and horizontal accelerations (Iverson and Hawkins 1994). A related question was asked to contractors, designers, and manufacturers. While the American respondents scored on average 0.93 , the Turkish respondents scored 1.57 (see Tables 2 and 3), a difference that has been found to be statistically significant at $\alpha=0.05$ by the Mann-Whitney test. The Turkish respondents' score is approximately 1.5 times higher than the score of the American respondents. This finding is not surprising in the current state of the Turkish construction industry, where most labourers are not formally trained; most of them are unskilled and underqualified (DPT Report 2004; Kazaz et al. 2008). According to Tokman and Eryilmaz (2004), Agrali (2006), and Polat (2008c), the inadequacy of the Turkish construction labour force is much as much 
a problem for the construction industry in general as it is for the precast concrete industry.

\section{- Conformity between different precast concrete systems}

Standardization and modularization are two of the major benefits that the use of precast concrete components promises. In this context, achieving conformity between different precast concrete components provided by more than one manufacturer for the same project plays a significant role in the project success. Individual endeavours of manufacturers in terms of setting companywide rules and strict procedures for production processes may help in achieving tighter control over quality; but, they are not adequate for overcoming compatibility problems caused by the non-standardization of the components (Polat 2008a). Indeed, the overall success of industrialized systems depends on the existence of nationwide standardization, well-defined policies for modularization, and quality control (Arditi et al. 2000; Polat 2008b). Contractors, designers, and manufacturers were asked to rate the importance of conformity problems on the low market share of precast concrete structures. The average importance scores given by the American and Turkish respondents are 1.09 (which is slightly higher than "fairly important") and 1.61 (which is higher than "fairly important"), respectively (see Tables 2 and 3). The Mann-Whitney test indicates a significant difference between the American and Turkish responses. It appears that poor standardization brings about severe conformity problems in Turkey more than in the U.S.

There may be three reasons why the poor standardization caused so much frustration in the Turkish precast concrete industry. First, only 25 of the 95 (26\%) manufacturers in Turkey are members of TPA. In contrast, the majority of American manufacturers are members of PCI; of the 300 manufacturers in the U.S. (Arditi et al. 2000), 247 have membership in PCI (82\%) (Membership Directory 2006). Second, TPA is not as active as PCI in setting and promoting rules for the nationwide standardization of production and quality control of precast concrete components. While PCI regularly audits all aspects of its member manufacturers' plant operations in place including the conformity of engineering practices and management commitment, TPA does that kind of audit only on request (TPA Report 2006). Third, most of the Turkish precast concrete manufacturers are small or middle sized companies (Tokman and Eryilmaz 2004), whereas the majority of the manufacturers in the U.S. are comparatively larger. Smaller companies may not have enough financial resources to allocate for quality control procedures and standards.

\section{- Labour unions' attitude}

Labour unions may not be one of the key actors in the U.S. precast concrete supply chains. However, since the use of precast concrete components reduces the amount of work on site (Alinaitwe et al. 2006), labour unions may tend to protect their workers by including prefabrica- tion clauses in their collective bargaining agreements with contractors (Arditi et al. 2000; Polat 2008b). Thus, labour unions' negative attitudes towards contractors may prevent the extensive use of precast concrete structures in the U.S. building construction market. Labour unions may play a role in the precast concrete industry in the U.S. to some extent; however, construction labour is not unionized in the Turkish construction industry. Therefore, labour unions were left out of the survey of Turkish respondents. When contractors, designers, and manufacturers were asked to rate how labour unions' negative attitude affects the use of precast concrete systems in the U.S. building construction market, the respondents scored on average 0.93 , which is slightly lower than "fairly important" (see Table 2). It appears that labour unions do not have a negative attitude towards contractors that use precast concrete components in their building projects. Thus, labour unions do not have a significant impact on the low market share of industrialized building systems in the U.S.

\section{- Occupants' level of satisfaction with precast concrete structures}

One of the major factors that prevent the extensive use of precast concrete systems may be the dissatisfaction of occupants. End users of the precast concrete structures may not be satisfied with the buildings where they live or work either in the architectural context, e.g., cracks, poor thermal insulation, moisture penetration, monotony resulting from repetitiveness, etc. or in the structural context, e.g., uncertain and inconsistent performance under high seismic loads, etc. (Arditi et al. 2000; Polat 2008a). A question related to this issue was asked to contractors, designers, and manufacturers. While American respondents scored on average 0.56 (which is higher than "not important"), Turkish respondents scored 1.02 (which is slightly higher than "fairly important") (see Tables 2 and 3 ). The average importance score of the Turkish respondents is approximately twice that of their American counterparts. The Mann-Whitney test indicates that the difference is statistically significant. The main reason behind this difference may be related to the structural context, namely the poor performance of precast concrete systems in recent earthquakes in Turkey (Tokman and Eryilmaz 2004; YEMAR Report 2006; Sezen and Whittaker 2006).

\subsection{Overall rankings}

Based on the survey results presented in Tables 2 and 3, both American and Turkish contractors considered size and load restrictions on transportation, lack of contractors specialized in precast concrete systems, and owners' incapability of providing good communication among parties as the three most important barriers to the extensive use of precast concrete systems. The Mann-Whitney test results indicate significant differences between the American and Turkish contractors' perceptions on lack of qualified structural engineers in precast concrete systems, lack of labourers specialized in precast concrete systems, and owners' incapability of providing good communication among parties at $95 \%$ confidence level. 
According to the survey results presented in Tables 2 and 3, while American designers ranked size and load restrictions on transportation, limited variety of precast concrete components, and cost of precast concrete components as the three most important factors that prevent the extensive use of precast concrete systems, Turkish designers considered size and load restrictions on transportation, lack of contractors specialized in precast concrete systems, and lack of qualified structural engineers in precast concrete systems as the three most important barriers to the extensive use of these systems. The MannWhitney test results indicate that there are significant differences between the American and Turkish designers' perceptions on inferior performance of precast concrete systems in earthquakes, lack of qualified structural engineers in precast concrete components, lack of contractors specialized in precast concrete systems, owners' incapability of providing good communication among parties, lack of labourers specialized in precast concrete systems, severe conformity problems between different precast concrete systems, and dissatisfaction of occupants at $95 \%$ confidence level.

It can be inferred from the survey results presented in Tables 2 and 3, both American manufacturers and Turkish manufacturers ranked owners' incapability of providing good communication among parties, lack of qualified structural engineers, and lack of qualified contractors specialized in precast concrete systems as the three most important factors that prevent the extensive use of these systems. The Mann-Whitney test results indicate significant differences between the American and Turkish contractors' perceptions on the limited variety of precast concrete components, severe conformity problems between different precast concrete systems, and dissatisfaction of occupants at $95 \%$ confidence level.

The survey results presented in Table 2 revealed that American respondents considered size and load restrictions on transportation, poor communication among parties, and lack of qualified contractors specialized in precast concrete systems as three most important barriers to the extensive use of precast concrete systems in the U.S. building construction market. They believe that dissatisfaction of occupants, inferior performance in earthquakes, lack of labourers specialized in precast concrete systems, and labour unions' negative attitude do not have a significant impact on the low use of these systems in the U.S building construction market. It can be inferred from the survey results presented in Table 3 that Turkish respondents ranked lack of good communication among parties and lack of structural engineers and contractors specialized in precast concrete systems as the most important three factors that prevent the extensive use of these systems in Turkey. In contrast to their American counterparts, Turkish respondents thought that all factors play at least a fairly important role in the low market share of these systems. The Mann-Whitney test results indicate significant differences between the American and Turkish respondents' perceptions on the impacts of inferior performance in earthquakes, lack of qualified workforce including structural engineers, contractors, and labourers specialized in precast concrete systems, severe conformity problems due to poor standardization, and dissatisfaction of occupants on the low market share of these systems at $95 \%$ confidence level.

\section{Conclusions}

The use of precast concrete technology offers significant potential advantages. Although precast concrete systems are extensively used in the northern European countries, their market share is very low both in the U.S. and in Turkey. A questionnaire survey was conducted to determine whether the perceptions of the American and Turkish respondents on the factors that prevent the extensive use of precast concrete systems are significantly different from each other.

While American respondents considered size and load restrictions on transportation, poor communication among parties, and lack of qualified contractors specialized in precast concrete systems as three most important barriers to the extensive use of precast concrete systems in the U.S. building construction market, Turkish respondents ranked lack of good communication among parties and lack of structural engineers and contractors specialized in precast concrete systems as the most important three factors that prevent the extensive use of these systems in Turkey. The Mann-Whitney test results indicate significant differences between the American and Turkish respondents' perceptions on most of the factors, namely 6 of the 11 factors, presented in Tables 2 and 3 that may prevent the extensive use of precast concrete systems at 95\% confidence level. The survey results revealed that most of the typical problems inherent in the construction industries of developing countries, such as low wages of construction labourers, lack of qualified workforce, lack of specialization, low usage of advanced technologies, poor project management capability of contractors, inferior nationwide standardization, etc., also prevail in the precast concrete industries of developing countries, namely Turkey, and these conditions differentiate the factors preventing the extensive use of precast concrete systems in developing and in industrialized countries, namely Turkey and the U.S.

This study is of benefit to both the precast concrete industry participants and researchers, because it identifies the main reasons why precast concrete systems are not used from the perspectives of a developing and a developed country, and shows them that the problems that should be solved immediately in order to promote the extensive use of these systems are different in these countries.

\section{Acknowledgments}

The funding for part of this study was provided by the Feyzi Akkaya Fund for Supporting Scientific Activities (FABED) and is gratefully acknowledged. 


\section{References}

Acar, E.; Kocak, I.; Sey, Y., and Arditi, D. 2005. Use of information and communication technologies by SMEs in building construction, Construction Management and Economics 23(7): 713-722. doi:10.1080/01446190500127112

Agrali, S. 2005. Prefabrikasyon insaatlarda, kisa sureli yapilasmaya hiz kazandiriyor, Dunya Insaat Dergisi, Nisan (in Turkish).

Agrali, S. 2006. Prefabrikasyon hizli, guvenli ve ekonomik yapilasmanin oncusu, Dunya Insaat Dergisi, Nisan (in Turkish).

Alinaitwe, H. M.; Mwakali, J. A., and Hansson, B. 2006. Assessing the degree of industrialisation in construction - A case of Uganda, Journal of Civil Engineering and Management 12(3): 221-229.

Alinaitwe, H. M.; Mwakali, J. A., and Hansson, B. 2007. Factors affecting the productivity of building craftsmen Studies of Uganda, Journal of Civil Engineering and Management 13(3): 169-176.

Alinaitwe, H. M.; Mwakali, J. A., and Hansson, B. 2009. Organizational effectiveness of Ugandan building firms as viewed by craftsmen, Journal of Civil Engineering and Management 15(3): 281-288.

doi:10.3846/1392-3730.2009.15.281-288

Arditi, D.; Ergin, U., and Gunhan, S. 2000. Factors affecting the use of precast concrete systems, Journal of Architectural Engineering 6(3): 79-86. doi:10.1061/(ASCE)1076-0431(2000)6:3(79)

Arslan, A. S.; Kaya, M., and Doyranli, B. 2003. Deprem bolgelerinde uygulanabilecek ard germeli on-uretimli kolonkiris birlesimleri uzerine deneysel bir calisma, in Fifth $\mathrm{Na}$ tional Conference on Earthquake Engineering, 121-130 (in Turkish).

Camba, J. L., and Meli, R. 1993. Case study of the performance of prestressed concrete buildings during the 1985 Mexico earthquake, PCI Journal 38(2): 62-70.

Chan, W. T., and Hu, H. 2002. Constraint programming approach to precast production scheduling, Journal of Construction Engineering and Management 128(6): 513-521. doi:10.1061/(ASCE)0733-9364(2002)128:6(513)

Conover, W. J. 1998. Practical Nonparametric Statistics. John Wiley \& Sons, Canada.

Directory of Contractors, ENR. McGraw-Hill, New York, 2006.

Directory of Design Firms, ENR. McGraw-Hill, New York, 2006.

DPT Report. 2004. Turkiye'de bilgi ekonomisine ve bilgi toplumuna gecis icin strateji ve politikalar, Izmir Iktisat Kongresi, 22. Calistayi (in Turkish).

Eastman, C.; Sacks, R., and Lee, G. 2003. Development and implementation of advanced IT in the North American precast concrete industry, ITCon International Journal of IT in Construction 8: 247-262.

Ergin, U. 1995. Industrialized Building Systems in the United States. MSc Thesis, Illinois Institute of Technology, Chicago, IL.

Field, A. 2005. Discovering Statistics using SPSS ( $2^{\text {nd }}$ Edition). Sage, London.

Hamill, P.; Bertolini, M.; Biebighauser, M.; Bechara, C. H., and Wilden, H. 2006. Precast concrete value engineering accommodates difficult sites, PCI Journal 51(4): 2-25.

Iverson, J. K., and Hawkins, N. M. 1994. Performance of precast / prestressed concrete building structures during Northridge earthquake, PCI Journal 39(2): 38-55.
Jang, W., and Skibniewski, M. J. 2008. A wireless network system for automated tracking of construction materials on project sites, Journal of Civil Engineering and Management 14(1): 11-19. doi:10.3846/1392-3730.2008.14.11-19

Kale, S., and Arditi, D. 2006. Diffusion of ISO 9000 certification in the precast concrete industry, Construction Management and Economics 24(May): 485-495. doi:10.1080/01446190600601594

Kaming, P. F.; Olomolaiye, P. O.; Corbett, P., and Harris, F. C. 1994. A framework for the strategic development of the construction industry in the developing countries, Building Research and Information 22(6): 325-331. doi:10.1080/09613219408727412

Kazaz, A.; Manisali, E., and Ulubeyli, S. 2008. Effect of basic motivational factors on construction workforce productivity in Turkey, Journal of Civil Engineering and Management 14(2): 95-106. doi:10.3846/1392-3730.2008.14.4

Lam, P. T. I.; Chan, A. P. C.; Wong, F. K. W., and Wong, F. W. H. 2007. Constructability rankings of construction systems based on the analytical hierarchy process, Journal of Architectural Engineering 13(1): 36-43. doi:10.1061/(ASCE)1076-0431(2007)13:1(36)

Manrique, J. D.; Al-Hussein, M.; Telyas, A., and Funston, G. 2007. Case study-based challenges of quality concrete finishing for architecturally complex structures, Journal of Construction Engineering and Management 133(3): 208216. doi:10.1061/(ASCE)0733-9364(2007)133:3(208)

Membership Directory, PCI, Chicago, 2006.

Muguruma, H.; Nishiyama, M., and Watanabe, F. 1995. Lessons learned from the Kobe earthquake: A Japanese perspective, PCI Journal 40(4): 28-42.

Neville, A. 2005. Some aspects of sustainability, PCI Journal 50(5): 2-5.

Norusis, M. J. 2000. SPSS10.0: Guide to Data Analysis. Prentice Hall, New Jersey.

OECD Report. 2004. Small and medium - sized enterprises in Turkey - issues and policies. Organization for Economic Co-operation and Development (OECD), Paris.

Oral, E. L.; Mistikoglu, G., and Erdis, E. 2003. JIT in developing countries - a case study of the Turkish prefabrication sector, Building and Environment 38: 853-860.

Polat, G. 2008a. Factors affecting the use of precast concrete systems in the Turkish Construction Industry, in Proceedings of $8^{\text {th }}$ International Congress on Advances in Civil Engineering, Famagusta, North Cyprus, 523-530.

Polat, G. 2008b. Factors affecting the use of precast concrete systems in the United States, Journal of Construction Engineering and Management 134(3): 169-178. doi:10.1061/(ASCE)0733-9364(2008)134:3(169)

Polat, G. 2008c. Unqualified workforce problem in industrialized building systems, in Proceedings of $4^{\text {th }} S C P M \& 1^{\text {st }}$ IPMA/MedNet Conference, Chios Island, Greece, 249-254.

Polat, G., and Damci, A. 2007. Need for qualified workforce in industrialized building systems: case of the Turkish precast concrete industry, in Proceedings of BEECON 2007 Conference, London, UK.

Priestley, M. J. N., and Tao, J. R. 1993. Seismic response of precast prestressed concrete frames with partially debonded tendons, PCI Journal 38(1): 58-69.

Sacks, R.; Eastman, C. M., and Lee, G. 2004. Process model perspectives on management and engineering procedures in the precast / prestressed concrete industry, Journal of Construction Engineering and Management 130(2): 206-215. doi:10.1061/(ASCE)0733-9364(2004)130:2(206) 
Sezen, H., and Whittaker, A. S. 2006. Seismic performance of industrial facilities affected by the 1999 Turkey earthquake, Journal of Performance of Constructed Facilities 20(1): 28-36.

doi:10.1061/(ASCE)0887-3828(2006)20:1(28)

Soetanto, R.; Glass, J.; Dainty, A. R. J., and Price, A. D. F. 2007. Structural frame selection: case studies of hybrid concrete frames, Building Research \& Information 35(2): 206-219. doi:10.1080/09613210600809029

Tam, V. W. Y.; Tam, C. M.; Zeng, S. X., and Ng, W. C. Y. 2007. Towards adoption of prefabrication in construction, Building and Environment 42(10): 3642-3654. doi:10.1016/j.buildenv.2006.10.003

Todd, P.; Rapp, J. G.; Charlson, K., and Holsteen, D. 2004. Aurora Municipal Center's stunning design showcases the possibilities of precast concrete solutions, PCI Journal 49(6): 80-93.

Tokman, B., and Eryilmaz, M. G. 2004. Prefabrike beton endustrisinin dunu, bugunu, yarini, Yapi 271: 95-100 (in Turkish).

TPA Report. 2006. Precast concrete industry annual report. Turkish Precast Concrete Association, Ankara (in Turkish).

UNEP Report. 2002. Industry as a partner for sustainable development: Construction. Confederation of International Contractors' Associations, United Kingdom.

VanGeem, M. 2006. Achieving sustainability with precast concrete, PCI Journal 51(1): 42-61.

YEMAR Report. 2006. Turkish construction sector report. Yemar, Istanbul (in Turkish).

\section{SURENKAMOJO GELŽBETONIO SISTEMOS BESIVYSTANČIOSE IR INDUSTRIALIZUOTOSE ŠALYSE G. Polat}

S a n tra u a

Surenkamojo gelžbetonio technologija visame pasaulyje pripažįstama dèl daugelio svarbių pranašumų. Nepaisant jų, surenkamojo gelžbetonio statybos sistemų dalis Turkijoje ir JAV, palyginti su kitomis Europos šalimis, yra labai maža. Turkija yra besivystanti šalis, kurios technologijų plètote priklauso nuo išsivysčiusių šalių, tad maža surenkamosios statybos sistemos dalis yra pagrista. Tačiau JAV yra išsivysčiusi ir industrializuota šalis, bet šių sistemų naudojimo mastas šalyje yra mažas. Remiantis išsamia apklausa straipsnyje atlikta mažą surenkamųjų betono sistemų naudojimo JAV ir Turkijoje apimti lemiančių veiksnių analizè. Apklausos rezultatai parodè, kad JAV ir Turkijos respondentų nuomoné dèl daugelio veiksnių labai skyrėsi. JAV respondentai nurodé, kad trys pagrindiniai veiksniai, ribojantys surenkamujju gelžbetonio sistemų naudojimą JAV statybos rinkoje, yra: transportavimo apribojimai dèl dydžio ir svorio; silpnas ryšys tarp statybos proceso dalyvių; kvalifikuotų statybos rangovų, kurių specializacija - surenkamieji statybos elementai, trūkumas. Turkijos respondentai pagrindinėmis priežastimis laiko bendradarbiavimo tarp statybos proceso dalyvių stoką ir specializuotų statybos projektuotojų bei rangovų trūkumą. Atlikta studija parodè, kad surenkamojo gelžbetonio sistemų naudotojai ir gamintojai turètų pripažinti, jog menka surenkamųų gelžbetonio sistemų naudojimo apimtis pirmiausia priklauso nuo šalyje dominuojančių statybos sąlygų.

Reikšminiai žodžiai: surenkamasis gelžbetonis, statinių sistemos, besivystančios šalys, industrializuotos šalys, anketa, Turkija, JAV.

Gul POLAT serves as Assistant Professor in the Faculty of Civil Engineering at Istanbul Technical University, Turkey. She conducted her PhD studies at Istanbul Technical University and Illinois Institute of Technology in Chicago. Her main areas of research interest include off-site manufacturing (e.g., precast concrete systems), marketing management, process modeling (e.g., simulation methods), business process reengineering, resource management, and most aspects of construction management. She has been involved with several research projects funded by Istanbul Technical University (ITU), Feyzi Akkaya Fund for Supporting Scientific Activities (FABED), and other construction industry agencies. Her research work over the years has resulted in 45 technical papers in refereed journals and proceedings. She is a member of Turkish Chamber of Civil Engineers and Lean Thinking Association. 